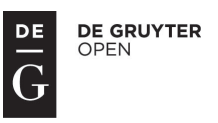

\title{
APPLiCATION OF Window MALMQUiST INDEX FOR EXAMINATION OF EFFICIENCY CHANGE OF CZECH COMMERCIAL BANKS
}

\author{
Iveta Palečková ${ }^{1}$
}

\begin{abstract}
The aim of the paper is to apply the Window Malmquist index approach to examine the efficiency change of Czech commercial banks within the period 2004-2013. We used the Data Envelopment Analysis and the Window Malmquist index approaches to estimate the efficiency change of Czech commercial banks. The average efficiency computed under the assumption of constant returns to scale was $73 \%$ and under the assumption of variable returns to scale the value was $83 \%$. We estimated the average positive efficiency growth of Czech commercial banks during the period 2004-2013. We found that average scale efficiency was $88 \%$, which means that Czech commercial banks were of an inappropriate size, especially the largest banks.
\end{abstract}

\section{Keywords}

Banking sector, Czech Republic, Data Envelopment Analysis, Window Malmquist Index

\section{Introduction}

Berger and Mester (1997) concluded that analysis of banking efficiency is an important topic both from a microeconomic and a macroeconomic perspective. From a microeconomic perspective, the efficiency of banks is important because of the increase in competition from foreign banks and the improvement of institutional regulation and supervision. From a macroeconomic perspective, the efficiency of the banking system influences the cost of financial intermediation and the stability of the entire financial system ${ }^{2}$. An improvement in the performance of banks indicates a better allocation of financial resources and, thus, an increase in investments favouring economic growth. Researching banking efficiency is therefore highly motivating as a topic of great importance. The other motivation for

\footnotetext{
${ }^{1}$ Silesian University in Opava, School of Business Administration in Karviná, Univerzitní náměstí 1934/3, 73340 Karviná, Czech Republic. E-mail: paleckova@opf.slu.cz.

${ }^{2}$ Rossi et al. (2005).
} 
this paper is applying a new dynamic approach for measuring banking efficiency and the extension of the empirical literature.

The aim of the paper is to apply the Window Malmquist index approach to examine the efficiency change of Czech commercial banks within the period 2004-2013. For the empirical estimation, we applied the Data Envelopment Analysis (DEA) and Window Malmquist index on data from Czech commercial banks. First, we estimate the efficiency of Czech commercial banks using a DEA model and then we estimate the efficiency change of commercial banks by applying the Window Malmquist index. The Window Malmquist index is constructed by combining Data Envelopment Analysis Window analysis with the Malmquist index approach. The Window Malmquist index is determined in order to investigate the levels of efficiency and changes in the efficiency of Czech commercial banks over the period analysed. By means of this approach, the technical efficiency is analysed sequentially with a certain window width (i.e. the number of years in a window) using panel data from Czech commercial banks. The Window Malmquist index is based on Data Envelopment Analysis models. DEA measures the relative efficiency of a homogeneous set of decision-making units in their use of multiple inputs to produce multiple outputs. We simultaneously use two alternative specifications of the DEA approach, specifically the CCR model and BCC model, which differ in returns to scale assumptions.

The Czech financial system is characterized as a bank-based system, and banks play an important role in the economy. That is why the identification of banking efficiency is an important topic for the banking industry. The transformation and consolidation of the banking sectors were carried out during the 1990s. The Czech Republic joined the European Union in 2004. From 2004-2013, the number of banks was almost constant, but the number of foreign bank branches increased. There were several mergers and acquisitions in the Czech banking market during the years analysed. In 2013, the number of banking institutions included 18 banks (four large banks, eight medium-sized banks and six small banks), five building societies and 21 foreign bank branches. The Czech banking sector has an almost stable shareholder structure. Foreign capital with a direct share has dominated the domestic banking sector's capital. In 2009 the small and open Czech economy was hit hard by the global financial and economic crisis. Thanks to its very strong deposit base and the very small percentage of loans denominated in foreign currency, the banking sector remained stable throughout the global financial crisis.

The structure of the paper is as follows. The following section describes empirical analysis of the efficiency of the Czech banking industry. The next section presents methodology and data: Data Envelopment Analysis and the Malmquist index and a selection of variables are described. Section four reveals estimated results and section five concludes the paper with a summary of the key findings. 


\section{Literature review}

Several empirical analyses of the efficiency of the Czech banking sector exist and we refer to some of them. Some empirical studies, e.g. Grigorian and Manole (2006), Yildirim and Philippatos (2007), Bems and Sorsa (2008), Matoušek (2008), Mamatzakis et al. (2008) or Baruník and Soták (2010) examined banking efficiency in several European countries and the Czech banking sector was included in the panel data.

Stavárek and Polouček (2004) estimated efficiency and profitability in selected banking sectors, including the Czech Republic, and found that the Czech banking sector showed itself to be the most aligned banking industry among transition countries. To achieve greater efficiency, a bank should be large, well-known, easily accessible and offer a wide range of products and services, or if small, must focus on specific market segments, offering special products. Any other structure leads to lower relative efficiency for the bank.

Stavárek (2005) estimated commercial bank efficiency in the group of Visegrad countries before joining the EU and concluded that the Czech banking sector is the most efficient; although there has been an improvement in levels of efficiency in all countries since 1999, its intensity was not sufficient to converge with Western European banking sectors.

Staněk (2010) compared the efficiency of the banking sector in the Czech Republic and Austria. The Stochastic Frontier Approach was employed to measure the efficiency of the banking sector. It was found that the efficiency of the Czech banking sector has improved in the last ten years and come closer to the efficiency of the Austrian banking sector. Stavárek and Repková (2012) found that efficiency increased in the period 2000-2010 and found that the largest banks perform significantly worse than medium-sized and small banks.

The results of Andries and Cocris (2010) showed that banks in the Czech Republic are inefficient from the perspective of costs. To improve efficiency, banks need to improve the quality of assets owned by improving the lending process and reducing the share of nonperforming loans. Anayiotos et al. (2010) estimated the relative efficiency of banks in emerging Europe before the recent boom, just before the crisis and right after the crisis using Data Envelopment Analysis. Their results suggested that banking efficiency decreased during the pre-crisis boom and also fell during the crisis.

There is a lack of studies in the Czech Republic examining banking efficiency using dynamic measures of banking efficiency and efficiency change. The network structure of Data Envelopment Analysis models was applied to Czech banks by Jablonský (2012). Řepková (2014) applied the Window DEA analysis on data from Czech commercial banks. Řepková (2013) also estimated the Czech banking sector using dynamic DEA.

We can conclude that in terms of empirical analysis there is a lack of studies in banking sectors examining efficiency change, which creates an opportunity for this research. As far as the author is aware, there exist in the empirical literature only a few studies which have estimated efficiency change in the Czech banking sector. E.g. Řepková (2012) estimated efficiency change in the Czech banking sector using the Malmquist index. Palečková (2015) or Hančlová and Staníčková (2012) measured the efficiency change in Visegrad 
countries, while Lyroudi and Angelidis (2006) estimated the efficiency change of selected countries of the European Union.

The author is aware of no study in the empirical literature which has applied the Window Malmquist index to the Czech banking sector. The Window Malmquist index was used by, e.g. Rezitis (2010), who applied this approach to measure changes in agricultural Total Factor Productivity for the United States and a sample of nine European countries for the period 1973 to 1993 . Thus, this paper could fill a gap in the empirical literature. The contribution of this paper is that a new approach, especially the Window Malmquist index, will be applied to data from Czech commercial banks.

\section{Methodology and Data}

The Data Envelopment Analysis window approach is used with the Malmquist index measurement in this study. The combined approach is referred to as the Window Malmquist index.

\section{Data Envelopment Analysis}

Data Envelopment Analysis is a mathematical programming technique that measures the efficiency of a decision-making unit (DMU) relative to other similar DMUs with the simple restriction that all DMUs lie on or below the efficiency frontier ${ }^{3}$. DEA also identifies, for inefficient DMUs, the sources and level of inefficiency for each of the inputs and outputs ${ }^{4}$. The $\mathrm{CCR}^{5}$ model presupposes that there is no significant relationship between the scale of operations and efficiency by assuming constant returns to scale (CRS) and it delivers overall technical efficiency. The CRS assumption is only justifiable when all DMUs are operating at an optimal scale. Banker et al. (1984) extended the CCR model by relaxing the CRS assumption. The resulting $\mathrm{BCC}^{6}$ model was used to assess the efficiency of DMUs characterized by variable returns to scale (VRS). The VRS assumption provides the measurement of pure technical efficiency (PTE), which is the measurement of technical efficiency devoid of scale efficiency (SE) effects.

DEA begins with a fractional programming formulation. Assume that there are $n$ DMUs to be evaluated. DMUj consumes xij amounts of input to produce yrj amounts of output. It is assumed that these inputs, xij, and outputs, yrj, are non-negative, and each DMU has at least one positive input and output value. The productivity of a DMU can be written as:

$$
h_{j}=\frac{\sum_{r=1}^{s} u_{r} y_{r j}}{\sum_{i=1}^{m} v_{i} x_{i j}},
$$

In this equation, $u$ and $v$ are the weights assigned to each input and output. By using mathematical programming techniques, DEA optimally assigns the weights subject to the following constraints. The weights for each DMU are assigned subject to the constraint

\footnotetext{
${ }^{3}$ Seiford and Thrall (1990).

${ }^{4}$ Charnes et al. (1995).

${ }^{5}$ Charnes, Cooper and Rhodes (1978).

${ }^{6}$ Banker, Charnes and Cooper (1984).
} 
that no other DMU has efficiency greater than 1 if it uses the same weights, implying that efficient DMUs will have a ratio value of 1 . The objective function of DMU is the ratio of the total weighted output divided by the total weighted input:

$$
\max h_{0}(u, v)=\frac{\sum_{r=1}^{s} u_{r} y_{r 0}}{\sum_{i=1}^{m} v_{i} x_{i 0}},
$$

subject to

$$
\begin{aligned}
\frac{\sum_{r=1}^{s} u_{r} y_{r j}}{\sum_{i=1}^{m} v_{i} x_{i j}} \leq 1, j=1,2 \ldots, j_{0}, \ldots, n \\
u_{r} \geq 0, \quad r=1,2, \ldots, s \\
v_{i} \geq 0, \quad i=1,2, \ldots, m
\end{aligned}
$$

where $h_{0}$ is the technical efficiency of $\mathrm{DMU}_{0}$ to be estimated, $u_{r}$ and $v_{i}$ are weights to be optimized, $y_{r j}$ is the observed amount of output of the $r^{t h}$ type for the $j^{t h}$ DMU, $x_{i j}$ is the observed amount of input of the $i^{t h}$ type for the $j^{t h}$ DMU, $r$ indicates the $s$ different outputs, $i$ denotes the $m$ different inputs and $j$ indicates the $n$ different $\mathrm{DMU}_{s}$. The conditions of the CCR and BCC models are described in Palečková (2015).

\section{Malmquist index}

The Malmquist index evaluates efficiency change over time. This index was introduced into the DEA literature by Caves et al. (1982) and is based on Malmquist's proposal to construct quantity indices as ratios of distance functions for use in consumption analysis ${ }^{7}$. Distance functions are representations of multi-output multi-input technologies which require data only on input and output quantities (Fare et al., 1994).

The Malmquist index (MI), based on DEA models, is one of the most prominent indexes for measuring the relative productivity change of DMUs in multiple time periods. This index breaks down into various components. The index provides a useful way of distinguishing between changes in technical efficiency, pure technical efficiency, scale, total factor productivity (TFPC) and shifts in the efficiency frontier (technological change) over time. This index is the geometric mean of two TFPC indices, one evaluated with respect to the technology (efficiency frontier) in the current period $t$ and the other with respect to the technology in the base period $s^{8}$. One extension with DEA is to apply the MI to panel data to estimate changes in technical efficiency, technological progress and total factor productivity.

The original idea of the Malmquist index was proposed by Malmquist (1953), who suggested comparing the input of a firm at two different points of time in terms of the maximum factor by which the input in one period could be decreased such that the firm could still produce the same output level of the other time period. Caves et al. (1982) extended the original Malmquist input index and introduced the first type of the Malmquist

\footnotetext{
${ }^{7}$ Jacobs at al. (2006).

${ }^{8}$ Coelli et al. (1998).
} 
index, and then Fare et al. (1992) showed that the Malmquist index can be calculated using a nonparametric DEA-like approach, given that suitable panel data are available and they applied DEA for measuring the Malmquist index. They assumed constant returns to scale and identified the technological change and the change of technical efficiency as two components of the productivity changes over time. Next, Fare et al. (1994) considered variable return to scale and offered an extended decomposition of the Malmquist index with another important factor capturing change in scale efficiency.

Following Fare et al. (1994) we use DEA to construct an input based MI between period $t$ (the base period) and period $s$ :

$$
M_{I}\left(y^{s}, x^{s}, y^{t}, x^{t}\right)=\left[\frac{D_{I}^{t}\left(y^{s}, x^{s}\right)}{\left(D_{I}^{t}\left(y^{t}, x^{t}\right)\right.} * \frac{D_{I}^{s}\left(y^{s}, x^{s}\right)}{D_{I}^{s}\left(y^{t}, x^{t}\right)}\right]^{\frac{1}{2}},
$$

where $M_{I}(\cdot)$ is the input-oriented $\mathrm{MI}, D_{I}^{t}\left(y^{s}, x^{s}\right)$ is the distance function showing a maximal proportional reduction of the observed period $s$ inputs under the period $t$ technology. The distance function is defined as follows:

$$
D_{I}^{t}\left(y^{s}, x^{s}\right)=\min _{\theta, \lambda} \theta
$$

subject to

$$
\begin{gathered}
y_{i s} \leq \lambda Y^{t}, \\
\theta x_{i s} \geq \lambda X^{t}, \\
\lambda_{i} \geq 0, i=1, \ldots n,
\end{gathered}
$$

where $\theta$ is a scalar and $\lambda$ is a vector of constants. The value of $\theta$ obtained is the component score of the $i$-th firm. $X$ and $Y$ are input and output vectors, and the amounts of the $i^{\text {th }}$ input consumed and output generated by the $\mathrm{DMU}_{0}$, are denoted by $x$ and $y$.

The above measure is actually the geometric mean of two Caves et al. (1982) Malmquist productivity indexes. Fare et al. (1992) define that $M_{I}>1$ indicates productivity gain; $M_{I}<1$ indicates productivity loss; and $M_{I}=1$ means no change in productivity from time $t$ to $s$. Relaxing Caves et al. (1982) assumption that $D_{I}^{t}\left(y^{t}, x^{t}\right)$ and $D_{I}^{s}\left(y^{t}, x^{t}\right)$ should equal to one, and allowing for technical inefficiency, Fare et al. (1992) decompose their Malmquist productivity index into two components:

$$
\begin{aligned}
M_{I} & =\left[\frac{D_{I}^{t}\left(y^{s}, x^{s}\right)}{D_{I}^{t}\left(y^{t}, x^{t}\right)} * \frac{D_{I}^{s}\left(y^{s}, x^{s}\right)}{D_{I}^{s}\left(y^{t}, x^{t}\right)}\right]^{\frac{1}{2}}= \\
& =\frac{D_{I}^{s}\left(y^{s}, x^{s}\right)}{D_{I}^{t}\left(y^{t}, x^{t}\right)}\left[\frac{D_{I}^{t}\left(y^{s}, x^{s}\right)}{D_{I}^{s}\left(y^{s}, x^{s}\right)} * \frac{D_{I}^{t}\left(y^{t}, x^{t}\right)}{D_{I}^{s}\left(y^{t}, x^{t}\right)}\right]^{\frac{1}{2}} .
\end{aligned}
$$

The first component $T E C=\frac{D_{I}^{s}\left(y^{s}, x^{s}\right)}{D_{I}^{t}\left(y^{t}, x^{t}\right)}$ measures the change in technical efficiency (technical efficiency change, TEC). The second component $T C C=\left[\frac{D_{I}^{t}\left(y^{s}, x^{s}\right)}{D_{I}^{s}\left(y^{s}, x^{s}\right)} *\right.$ 
$\left.\frac{D_{I}^{t}\left(y^{t}, x^{t}\right)}{D_{I}^{s}\left(y^{t}, x^{t}\right)}\right]^{\frac{1}{2}}$ measures the technology frontier shift (technological change, TCC) between time period $t$ and $s$. TCC can be seen as an average aggregated change in technology of a DMU from time period $t$ to $s$.

Fare et al. $(1992,1994)$ point out that a value of $T C C>1$ indicates a positive shift or technical progress, a value of $T C C<1$ indicates a negative shift or technical regress, and value of $T C C=1$ indicates no shift in technology frontier. In this paper we use the decomposition of Malmquist index into two components, namely technological change and efficiency change $\left(E C=\frac{D_{C R S}^{s}\left(y^{s}, x^{s}\right)}{D_{C R S}^{t}\left(y^{t}, x^{t}\right)}\right)$, which is a catch-up effect.

Figure 1: Malmquist index and efficiency change over time

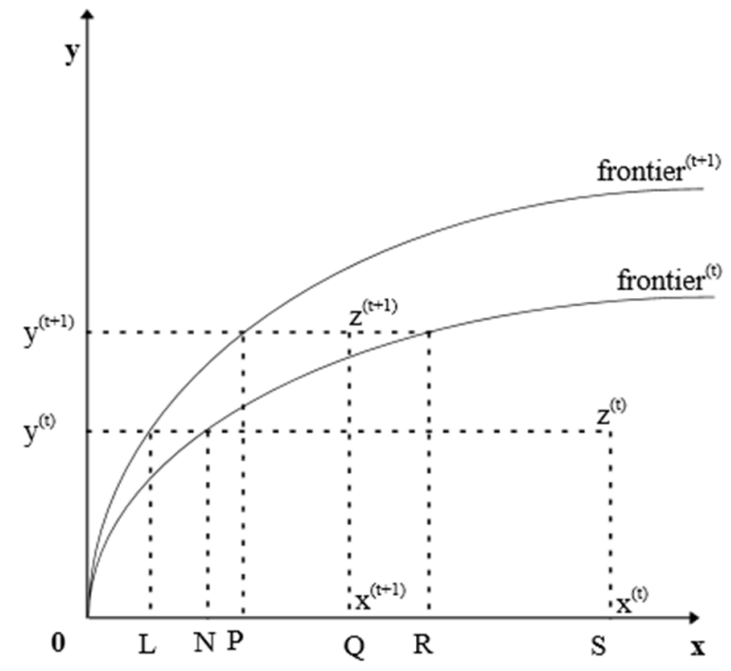

Source: Worthington (1999)

A graphical illustration is described in Figure 1, where a production frontier representing the efficient level of output $(y)$ that can be produced from a given level of input $(x)$ is constructed. We measure the efficiency change of DMU A by examining its efficiency in two time periods, $t$ and $t+1$, and also the technology shift from $t$ to $t+1$. The frontiers thus obtained in the current $(t)$ and future $(t+1)$ time periods are labelled accordingly. When inefficiency is assumed to exist, the relative movement of any given financial institution over time will therefore depend on both its position relative to the corresponding frontier (technical efficiency) and the position of the frontier itself (technical change). If inefficiency is ignored, then productivity growth over time will be unable to distinguish between improvements that derive from a financial institution catching up to its own frontier, or those that result from the frontier itself shifting up over time.

Now for any given financial institution in period $t$, represented by the input/output bundle $z(t)$, an input-based measure of efficiency can be deduced by the horizontal distance ratio 
$0 N / 0 S$. That is, inputs can be reduced in order to make production technically efficient in period $t$ (i.e. movement onto the efficient frontier). By comparison, in period $t+1$ inputs should be multiplied by the horizontal distance ratio $0 R / 0 Q$ in order to achieve comparable technical efficiency to that found in period $t$. Since the frontier has shifted, $0 R / 0 Q$ exceeds unity, even though it is technical inefficient when compared to the period $t+1$ frontier ${ }^{9}$.

\section{Window Analysis}

Window analysis is one of the methods used to verify productivity change over time. Window analysis technique works on the principle of moving averages ${ }^{10}$. DEA window analysis was proposed by Charnes et al. (1985) in order to measure efficiency in cross sectional and time varying data. Thus, it is useful in detecting performance trends of a decision-making unit over time. Each DMU (i.e. bank) in a different period is treated as if it were a different DMU (independent), but remains comparable in the same window ${ }^{11}$. Such capability in the case of a small number of DMUs and a large number of inputs and outputs would increase the discriminatory power of the DEA models ${ }^{12}$. Therefore, the problem of small sample sizes can be solved. In other words, the DEA window analysis technique is designed to examine how much a DEA efficiency score is changed by shifting a combination of adjacent periods referred to as a window ${ }^{13}$.

The number of banks that can be analyzed using the DEA model is virtually unlimited. Therefore, data on banks in different periods can be incorporated into the analysis by simply treating them as if they represent different banks. In this way, a given bank at a given time can compare its performance at different times and with the performance of other banks at the same and at different times. Through a sequence of such windows, the sensitivity of a bank's efficiency score can be derived for a particular year according to changing conditions and a changing set of reference banks. A bank that is DEA efficient in a given year, regardless of the window, is likely to be truly efficient relative to other banks. Conversely, a bank that is only DEA efficient in a particular window may be efficient solely because of extraneous circumstances. In addition, window analysis provides some evidence of the short-run evolution of efficiency for a bank over time. Of course, comparisons of DEA efficiency scores over extended periods may be misleading (or worse) because of significant changes in technology and the underlying economic structure (Yue, 1992).

Following Asmild et al. (2004) and Gu and Yue (2011), consider $N$ DMUs $(n=$ $1,2, \ldots, N)$ observed in $T(t=1,2, \ldots, T)$ periods using $r$ inputs to produce $s$ outputs. Let $D M U_{n}^{t}$ represent an $D M U_{n}$ in period $t$ with a $r$ dimensional input vector $x_{n}^{t}=\left(x_{n}^{1 t}, x_{n}^{2 t}, \ldots, x_{n}^{n}\right)^{\prime}$ and $s$ dimensional output vector $y=\left(y_{n}^{1 t}, y_{n}^{2 t}, \ldots, y_{n}^{s t}\right)^{\prime}$. If a window starts at time $k(1 \leq k \leq T)$ with window width $w(1 \leq w \leq t-k)$, then the

\footnotetext{
${ }^{9}$ Worthington (1999).

${ }^{10}$ Charnes et al. (1995), Yue (1992), Cooper et al. (2007).

${ }^{11}$ Cooper et al. (2011).

${ }^{12}$ Cooper et al. (2011).

13 Sueyoshi and Aoki (2001).
} 
metric of inputs is given as follows:

$$
x_{k w}=\left(x_{1}^{k}, x_{2}^{k}, \ldots, x_{N}^{k}, x_{1}^{k+1}, x_{2}^{k+1}, \ldots, x_{N}^{k+1}, x_{1}^{k+w}, x_{2}^{k+w}, \ldots, x_{N}^{k+w}\right)^{\prime},
$$

The metric of outputs as:

$$
y_{k w}=\left(y_{1}^{k}, y_{2}^{k}, \ldots, y_{N}^{k}, y_{1}^{k+1}, y_{2}^{k+1}, \ldots, y_{N}^{k+1}, y_{1}^{k+w}, y_{2}^{k+w}, \ldots, y_{N}^{k+w}\right)^{\prime}
$$

The CCR model of the DEA window problem for $D M U_{t}^{k}$ is given by solving the following linear program:

$$
\begin{gathered}
\min \theta, \\
\theta^{\prime} X_{t}-\lambda^{\prime} X_{k w} \geq 0,
\end{gathered}
$$

subject to

$$
\begin{gathered}
\lambda^{\prime} Y_{k w}-Y_{t} \geq 0, \\
\lambda_{n} \geq 0 \quad(n=1,2, \ldots, N \times w) .
\end{gathered}
$$

BCC model formulation can be obtained by adding the restriction $\sum_{n=1}^{n} \lambda_{n}=1^{14}$. The objective value of CCR model is designated technical efficiency and the objective of BCC model is pure technical efficiency. The BCC model is illustrated as:

$$
\begin{gathered}
\min \theta \\
\theta^{\prime} X_{t}-\lambda^{\prime} X_{k w} \geq 0,
\end{gathered}
$$

subject to

$$
\begin{gathered}
\lambda^{\prime} Y_{k w}-Y_{t} \geq 0, \\
\sum_{n=1}^{n} \lambda_{n}=1, \\
\lambda_{n} \geq 0 \quad(n=1,2, \ldots, N \times w) .
\end{gathered}
$$

Asmild et al. (2004) point out that there are no technical changes within each of the windows because all DMUs in each window are compared and contrasted against each other and suggest a narrow window width should be used. In order to be sure that the results will be credible, a narrow window width must be used. Therefore, a two-year window has been chosen for this paper $(w=2)$.

${ }^{14}$ Banker et al. (1984). 


\section{Data and selection of variables}

The data set used in this study was obtained from the annual reports of commercial banks during the period 2004-2013 and all the data is reported on an unconsolidated basis. We analysed only those commercial banks operating as independent legal entities. As we have reliable data extracted directly from annual reports, we eliminate the risk that incomplete or biased data may distort the estimation results.

In order to conduct the DEA estimation, inputs and outputs need to be defined. In the empirical literature four main approaches have been developed to define the input-output relationship in financial institution behaviour (intermediation, production, asset and profit approach). We adopt the intermediation approach, which assumes that the banks' main aim is to transform liabilities (deposits) into loans (assets). The bank collects deposits to transform them in loans. In accordance with this approach, we assume that banks use two inputs (labour and deposits), and two outputs (loans and net interest income). We measure labour by the total personnel costs covering wages and all associated expenses and deposits by the sum of demand and time deposits from customers, interbank deposits and sources obtained by bonds issued. Loans are measured by the net value of loans to customers and other financial institutions and net interest income as the difference between interest incomes and interest expenses. Descriptive statistics of inputs and outputs is presented in Table 1.

Table 1: Descriptive statistics (in mil. CZK) Rate of unemployment and inflation rate in the Czech Republic

\begin{tabular}{|l|cccc|}
\hline Variable & Deposits & Labour & Loans & NII \\
\hline Mean & 156845.1 & 2070.701 & 108460.7 & 5970.851 \\
Median & 52364.7 & 735 & 39059 & 1508.6 \\
Max & 636662 & 8525 & 472886 & 29460 \\
Min & 111.5 & 20.5 & 0 & 2 \\
St. Dev. & 192395.1 & 2518.894 & 128213.2 & 7735.203 \\
\hline
\end{tabular}

Source: Author's calculation based on annual reports of individual banks

\section{Empirical analysis and results}

DEA can be used to estimate efficiency under the assumptions of constant and variable returns to scale. For empirical analysis we use MaxDEA software. We adopted SBM (slack based model - non-radial) models created by Tone (2001), which are non-radial measures of efficiency. We used a combination of Window DEA analysis and the Malmquist index to examine the efficiency change of Czech commercial banks. Banking efficiency has been estimated using the Window DEA models, an input-oriented model with constant returns to scale and input-oriented model with variable returns to scale. We applied the Window Malmquist index and a two-year window has been chosen for this paper. We used unbalanced panel data from 16 Czech commercial banks (with regard to mergers and acquisitions of banks). 
First, the development of average banking efficiency is presented. Figure 2 shows the average efficiency score in the Czech banking sector estimated in the CCR and BCC model. The average efficiency calculated in the assumption of a constant return to scale reached a value of 55-84\%. On the other hand, average efficiency with variable return to scale was between $70 \%$ and $95 \%$. Average efficiency was increasing during the period 2005-2008. During the period 2009-2011, average efficiency was decreasing. This was probably caused by the financial crisis. In 2012 and 2013, average efficiency increased.

The large volume of information derived from DEA may be difficult to summarize and evaluate. Therefore, it is often helpful to break down the information using the Window Malmquist index. We calculate the Window Malmquist index from the DEA scores between adjacent periods. The application of the Window Malmquist index is also conducted in MaxDEA software. The Window Malmquist change indices are computed using DEA. The indices measure WMI for sampled banks in adjacent years during the period from 2004/2005 to 2012/2013. Following Asmild et al. (2004) we do not decompose this into technological change (TCC) and efficiency change (EC).

Figure 2: Average efficiency score estimated in CCR and BCC model

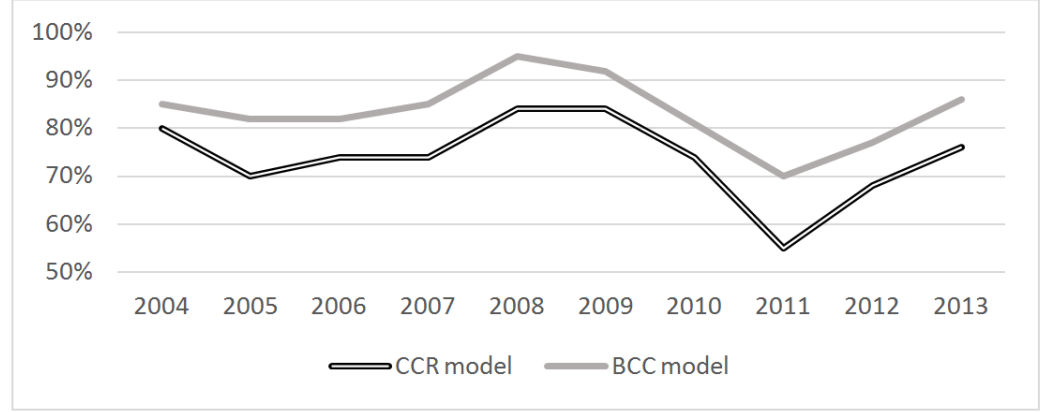

Source: Author's calculation

Table 2 presents the results of the average Window Malmquist indices of the Czech banking sector during the period analysed. Malmquist indices estimates are summarised below. The annual entries in each column in Table 2 are geometric means of results for individual banks and the period results reported in the last row are geometric means of the annual geometric means.

Table 2: Average Malmquist indices in banking sectors estimated in CCR model

\begin{tabular}{|c|c|}
\hline Period & WMI \\
\hline $2004-2005$ & 1.06 \\
$2005-2006$ & 1.10 \\
$2006-2007$ & 1.10 \\
$2007-2008$ & 1.04 \\
$2008-2009$ & 1.01 \\
$2009-2010$ & 0.89 \\
\hline
\end{tabular}

Continued on next page 


\begin{tabular}{|c|c|}
\hline Period & WMI \\
\hline $2010-2011$ & 0.98 \\
$2011-2012$ & 1.25 \\
$2012-2013$ & 1.04 \\
Mean & 1.05 \\
\hline
\end{tabular}

Source: Author's calculation

In the Czech banking sector, the average Window Malmquist index ranges around 1.05 in the CCR model. This shows positive efficiency change. This means that the average Window Malmquist index reaches annual average growth of 5\% in the CCR model during the period 2004-2013.

Table 3: Average Malmquist indices of Czech commercial banks estimated in CCR model

\begin{tabular}{|l|c|c|}
\hline DMU & Efficiency & WMI \\
\hline Air Bank & 0.51 & 1.62 \\
CitiBank & 0.73 & 0.98 \\
Ceska sporitelna & 0.76 & 1.04 \\
CSOB & 0.55 & 1.03 \\
eBanka & 0.69 & 1.00 \\
Evropsko-Ruska banka & 0.63 & 0.86 \\
GE Money Bank & 0.99 & 1.03 \\
JT Bank & 0.82 & 1.00 \\
Komercni banka & 0.69 & 1.04 \\
LBBW & 0.72 & 1.08 \\
Equa bank & 0.56 & 0.96 \\
PPF Bank & 0.82 & 1.06 \\
Raiffeisenbank & 0.74 & 1.05 \\
Sberbank & 0.93 & 1.03 \\
UniCredit bank & 0.86 & 1.04 \\
Zivnostenska banka & 0.91 & 1.05 \\
\hline
\end{tabular}

Source: Author's calculation

When we analysed each commercial bank (Table 3), we found that in the CCR model most banks reached a Window Malmquist index of above 1.00, which means that most banks underwent positive efficiency change during the period 2004-2013. Air bank reached the highest value of Window Malmquist index. But on the other hand, Air Bank was the least efficient bank in the Czech banking sector. A regress in efficiency change was seen in CitiBank, Evropsko-Ruska Banka and Equa bank. The group of the largest banks (CSOB, Ceska sporitelna and Komercni banka) registered positive values of efficiency change, while the efficiency growth for large banks was 3-4\%. 
Table 4: Average Malmquist indices in banking sectors estimated in BCC model

\begin{tabular}{|c|c|}
\hline Period & WMI \\
\hline $2004-2005$ & 1.06 \\
$2005-2006$ & 1.12 \\
$2006-2007$ & 1.11 \\
$2007-2008$ & 1.05 \\
$2008-2009$ & 1.00 \\
$2009-2010$ & 0.95 \\
$2010-2011$ & 0.98 \\
$2011-2012$ & 1.01 \\
$2012-2013$ & 1.04 \\
Mean & 1.03 \\
\hline
\end{tabular}

Source: Author's calculation

The results of the average WMI of the banking sector in the model with variable return to scale is presented in Table 4. The average WMI reaches annual average growth of $3 \%$ in the BCC model. A year-by-year score shows that the efficiency change was above 1.00 in the period 2005-2007 and then 2011-2013. In other periods, the average annual efficiency change was below 1.00. During the period 2009-2011, this negative efficiency change was probably as a result of the financial crisis. Thus, over the whole period average, the Window Malmquist index ranges around 1.03 in the BCC model in the Czech banking sector. This therefore demonstrates positive efficiency change.

Table 5: Average Malmquist indices of Czech commercial banks estimated in BCC model

\begin{tabular}{|l|cccc|}
\hline DMU & Efficiency & EC & TCC & WMI \\
\hline Air Bank & 0.70 & 1.23 & 0.91 & 1.13 \\
CitiBank & 0.74 & 0.95 & 1.04 & 0.99 \\
Ceska sporitelna & 1.00 & 1.00 & 1.02 & 1.02 \\
CSOB & 0.70 & 1.00 & 1.05 & 1.06 \\
eBanka & 0.69 & 0.96 & 1.04 & 1.00 \\
Evropsko-Ruska banka & 0.81 & 0.96 & 0.92 & 0.89 \\
GE Money Bank & 1.00 & 1.00 & 1.06 & 1.06 \\
JT Bank & 0.84 & 0.97 & 1.04 & 1.00 \\
Komercni banka & 0.95 & 1.00 & 1.10 & 1.10 \\
LBBW & 0.74 & 1.02 & 1.07 & 1.09 \\
Equa bank & 0.71 & 0.92 & 0.97 & 0.89 \\
PPF Bank & 0.84 & 1.01 & 1.03 & 1.05 \\
Raiffeisenbank & 0.84 & 1.02 & 1.06 & 1.08 \\
Sberbank & 0.96 & 0.99 & 1.06 & 1.05 \\
UniCredit bank & 0.97 & 1.00 & 1.12 & 1.12 \\
Zivnostenska banka & 0.93 & 1.02 & 1.03 & 1.05 \\
\hline
\end{tabular}

Source: Author's calculation 
Table 5 presents average Window Malmquist indices of individual commercial banks using variable return to scale. The results of the BCC model are similar to the results of the CCR model. Most banks reached positive efficiency growth during the period 2004-2013. The average efficiency growth of $13 \%$ was at Air Bank and average annual growth $12 \%$ was at UniCredit bank. Negative average growth in efficiency was registered in CitiBank, Evropsko-Ruska banka and Equa bank. The regress in the efficiency of CitiBank was due to worse innovation and management. The regress in the efficiency of Evropsko-Ruska banka and Equa bank was caused by worse innovation as well as regress in terms of technology.

In the assumption of variable return to scale, the largest banks also attained average growth of efficiency, while the efficiency growth of large banks was 2-6\%.

Next, we decompose efficiency to pure technical efficiency (PTE) and the scale efficiency (SE) components presented in Table 6. The value of scale efficiency is in a range of zero to one (respectively $0-100 \%$ ). If $\mathrm{SE}=100 \%$, this means that bank is scale efficient and the bank is operating at its optimal size. If SE $<100 \%$, the bank has some degree of inefficiency due to inadequate size.

Table 6: Average scale efficiency of Czech commercial banks

\begin{tabular}{|l|ccc|}
\hline DMU & TE & PTE & SE \\
\hline Air Bank & $51 \%$ & $70 \%$ & $73 \%$ \\
CitiBank & $73 \%$ & $74 \%$ & $99 \%$ \\
CS & $76 \%$ & $100 \%$ & $76 \%$ \\
CSOB & $55 \%$ & $70 \%$ & $79 \%$ \\
eBanka & $69 \%$ & $69 \%$ & $100 \%$ \\
Evropsko-Ruska banka & $63 \%$ & $81 \%$ & $78 \%$ \\
GE Money Bank & $99 \%$ & $100 \%$ & $99 \%$ \\
JT Bank & $82 \%$ & $84 \%$ & $98 \%$ \\
Komercni banka & $69 \%$ & $95 \%$ & $73 \%$ \\
LBBW & $72 \%$ & $74 \%$ & $97 \%$ \\
Equa bank & $56 \%$ & $71 \%$ & $79 \%$ \\
PPF Bank & $82 \%$ & $84 \%$ & $98 \%$ \\
Raiffeisenbank & $74 \%$ & $84 \%$ & $88 \%$ \\
Sberbank & $93 \%$ & $96 \%$ & $97 \%$ \\
UniCredit bank & $86 \%$ & $97 \%$ & $89 \%$ \\
Zivnostenska banka & $91 \%$ & $93 \%$ & $98 \%$ \\
Mean & $73 \%$ & $83 \%$ & $88 \%$ \\
\hline
\end{tabular}

Source: Author's calculation

An indication of the major source of efficiency change can be obtained by recalling that overall technical efficiency is the product of pure technical efficiency and scale efficiency. Thus, if PTE $>$ SE then the major source of efficiency change (both increase and decrease) 
is improvement in pure technical efficiency, whereas if PTE $<$ SE the major source of efficiency is an improvement in scale efficiency. Further details on the interpretation of these indices may be found in Charnes et al. (1995). We can see that, for the largest banks, the major source of efficiency change was improvement in pure technical efficiency. Average scale efficiency was $88 \%$, which means that the scale inefficiency of Czech commercial banks was $12 \%$. This means that several commercial banks were of inappropriate size. The highest value of scale efficiency $(100 \%)$ was registered in eBanka, which means that eBanka was operating at an adequate size. On the other hand, the large commercial banks (CSOB, Ceska sporitelna and Komercni banka) reached the lowest value of scale efficiency and the average scale efficiency was 73-79\%. This shows that the largest banks are of inadequate size. Also, AirBank, one of the small banks, was at a higher value of scale inefficiency.

\section{Conclusion}

The aim of this paper was to estimate the efficiency of Czech commercial banks during the period 2001-2011. We applied Dynamic Data Envelopment Analysis to data from Czech commercial banks. We estimated efficiency under the assumptions of constant and variable returns to scale. In the period analysed, average efficiency was calculated using constant returns to scale ranging from $80 \%$ to $92 \%$ and average efficiency computed using variable returns to scale ranged from $90 \%$ to $98 \%$. The average inefficiency of the Czech banking sector in the CCR model was $13 \%$ and average inefficiency in the BCC model reached $4 \%$. The reason for the inefficiency of Czech banks was mainly an excess of client deposits in the balance sheet of banks. We found that the efficiency score increased in the period 2001-2003. This increase was probably caused by better management in privatized banks. In 2005, average efficiency decreased. This was influenced by a decrease in loans and net interest income in several banks, a situation which was probably caused by the fact that the CNB increased the basic interest rate in 2005. During the period 2006-2009, the efficiency of the Czech banking sector was increasing and the structure of the financial market stabilized. In 2010 and 2011, average efficiency decreased as a result of the financial crisis.

The results of this paper could be used by managers of banks. We can demonstrate this with a short example: if, e.g. ČSOB were to reduce its inputs (deposit and personal costs) to $79 \%$ of current inputs, this bank would operate on an efficient frontier. DEA could provide the optimal proportion of inputs and outputs for each banks in the banking sectors. But this recommendation is not the aim of this paper and this is therefore a topic for further research.

We found that the highest value achieved for average efficiency was for Volksbank and GE Money Bank. In contrast, the lowest bank efficiency in the CCR model was represented by CSOB, Komercni banka and Ceska sporitelna. These banks, which are the three largest banks in the Czech banking sector, attained the lowest values in scale efficiency. Thus, the largest banks are the least efficient in the Czech banking industry. These large banks reached a higher value in the $\mathrm{BCC}$ model, demonstrating that large banks are too large and have improperly chosen their size (range of operations). The reason for this inefficiency 
is that the large banks have an excess of deposits on their balance sheet. Thus, the excess of deposits reflected negatively on net interest income by increasing the interest costs of banks. The second source of inefficiency of the largest commercial banks is fixed assets. The recommendation of the results of DEA is to reduce the client deposits and fixed assets.

\section{Acknowledgements}

Research for this paper was supported by the Internal Grant System of the Silesian University under the project IGS/6/2015 "Application of Window Malmquist approach for estimation of the Czech banking sector".

\section{References}

Anayiotos, G., Toroyan, H., Vamvakidis, A. (2010). The efficiency of emerging Europe's banking sector before and after the recent economic crisis. Financial Theory and Practice, 34(3), 247-267.

Andries, A. M., Cocris, V. (2010). A Comparative Analysis of the Efficiency of Romanian Banks. Romanian Journal of Economic Forecasting, 4, 54-75.

Asmild, M., Paradi, J. C., Aggarwall, V., Schaffnit, C. (2004). Combining DEA Window Analysis with the Malmquist Index Approach in a Study of the Canadian Banking Industry. Journal of Productivity Analysis, 21(1), 67-89.

Banker, R. D., Charnes, A., Cooper, W. W. (1984). Some Models for Estimating Technical and Scale Inefficiencies in Data Envelopment Analysis. Management Science, 30, 1078-1092.

Baruník, J., Soták, B. (2010). Influence of Different Ownership Forms on Efficiency of Czech and Slovak Banks: Stochastic Frontier Approach. Politická ekonomie, 2010(2), 207-224.

Bems, R., Sorsa, P. (2008). Efficiency of the Slovene Banking Sector in the EU context. Journal for Money and Banking, 57, 11.

Berger, A. N., Mester, L. J. (1997). Inside the black box: What explains differences in the efficiencies of financial institutions? Journal of Banking and Finance, 21, 895-947.

Caves, D. C., Christensen, L. R., Dievert, W. E. (1982). The economic theory of index number and the measurement of input, output, and productivity. Econometrica, 50, 1393-1414.

Charnes, A., Clark, T., Cooper, W. W., Golany, B. (1985). A developmental study of data envelopment analysis in measuring the efficiency of maintenance units in U. S. Air Forces. In: Thompson, R., Thrall, R.M. (Eds.). Annals of Operational Research, 2, 95-112.

Charnes A., Cooper, W. W., Lewin, A. Y., Seiford L. M. (1995). Data Envelopment Analysis: Theory, Methodology and Applications. New York: Springer-Verlag.

Charnes, A., Cooper, W. W., Rhodes, E. (1978). Measuring the Efficiency of Decision Making Units. European Journal of Operational Research, 2, 429-444.

Coelli, T. J., Prasada Rao, D. S., Battese, G. E. (1998). An Introduction to Efficiency and Productivity Analysis. Boston: Kluwer Academic Publishers. 
Cooper, W. W., Seiford, L. M., Zhu, J. (2011). Handbook on Data Envelopment Analysis. New York: Springer Science + Business Media.

Cooper, W., Seiford, L. M., Tone, K. (2007). Data Envelopment Analysis: A Comprehensive Text with Models Applications. New York: Springer Science.

Fare, R., Grosskopf, S., Lindgren, B., Roose, P. (1992). Productivity change in Swedish analysis, Pharmacies 1980-1989: A nonparametric Malmquist approach. Journal of Productivity, 3, 85-102.

Fare, R., Grosskopf, S., Norris, M., Zhang, A. (1994). Productivity growth, technical progress, and efficiency changes in industrial country. American Economic Review, 84, 66-83.

Grigorian, D., Manole, V. (2006). Determinants of Commercial Bank Performance in Transition: An Application of Data Envelopment Analysis. Comparative Economic Studies, 48(3), 497-522.

Gu, H., Yue, J. (2011). The Relationship between Bank Efficiency and Stock Returns: Evidence from Chinese Listed Banks. World Journal of Social Sciences, 1(4), 95-106.

Hančlová, J., Staníčková, M. (2012). Assessment of the Visegrad Countries Performance by Application of the DEA Based Malmquist Productivity Index. In Advances in Economics, Risk Management, Political and Law Science, proceedings of the 1st WSEAS International Conference on Economics, Political and Law Science (EPLS '12). Zlín: Tomas Bata University.

Jablonský, J. (2012). Data envelopment analysis models with network structure. In: Ramík, J., Stavárek, D. (Eds.). Proceedings of the 30th International Conference Mathematical Methods in Economics 2012. Karviná: Silesian University, School of Business Administration.

Jacobs, R., Smith, P. C., Street A. (2006). Measuring Efficiency in Health Care Analytic Techniques and Health Policy. Cambridge: Cambridge University Press.

Lyroudi, K., Angelidis, D. (2006). Measuring Banking Productivity of the Most Recent European Union Member Countries; A Non-Parametric Approach. Journal of Economics and Business, 9(1), 37-57.

Malmquist, S. (1953). Index numbers and indifference surfaces. Trabajos de Estadistica, 4, 209-242.

Mamatzakis, E., Staikouras, C., Koutsomanoli-Filippaki, A. (2008). Bank efficiency in the new European Union member states: Is there convergence? International Review of Financial Analysis, 17(5), 1156-1172.

Matoušek, R. (2008). Efficiency and scale economies in banking in new EU countries. International Journal of Monetary Economics and Finance, 1(3), 235-249.

Palečková, I. (2015). Efficiency Change in Banking Sectors of Visegrad Countries. In Proceedings of the 7th International Scientific Conference Finance and the Performance of Firms in Science, Education, and Practice. Zlín: Tomas Bata University.

Rezitis, A. N. (2010). Agricultural productivity and convergence: Europe and the United States. Applied Economics, 42(8), 1029-1044. 
Rossi, S. P. S., Schwaiger, M., Winkler, G. (2005). Managerial behavior and cost/profit efficiency in the banking sectors of Central and Eastern European countries. Working paper No. 96. Wien: Oesterreichische Nationalbank.

Řepková, I. (2012). Measuring the efficiency in the Czech banking industry: Data Envelopment Analysis and Malmquist index. In: Proceedings of 30th International Conference Mathematical Methods in Economics. Silesian University, School of Business Administration, Karviná.

Řepková, I. (2013). Estimation of Banking Efficiency in the Czech Republic: Dynamic Data Envelopment Analysis. DANUBE: Law and Economics Review, 4(4), 261-275.

Řepková, I. (2014). Efficiency of the Czech banking sector employing the DEA window analysis approach. Procedia Economics and Finance, 12, 587-596.

Seiford, L. M., Thrall, R. M. (1990). Recent developments in DEA: the mathematical programming approach to frontier analysis. Journal of Econometrics, 46, 7-38.

Staněk, R. (2010). Efektivnost českého bankovního sektoru v letech 2000-2009. In: Konkurenceschopnost a stabilita. Brno: Masaryk University.

Stavárek, D. (2005). Restrukturalizace bankovních sektorů a efektivnost bank v zemích Visegrádské skupiny. Karviná: Silesian University, School of Business Administration.

Stavárek, D., Polouček, S. (2004). Efficiency and Profitability in the Banking Sector. In: Polouček, S. (Ed.). Reforming the Financial Sector in Central European Countries. Palgrave Macmillan Publishers, Hampshire.

Stavárek, D., Řepková, I. (2012). Efficiency in the Czech banking industry: A nonparametric approach. Acta Universitatis Agriculturae et Silviculturae Mendeleianae Brunensis, 60, 357-366.

Sueyoshi, T., Aoki, S. (2001). A use of a nonparametric statistic for DEA frontier shift: the Kruskal and Wallis rank test. Omega, 29, 1-18.

Worthington, A. C. (1999). Malmquist Indices of Productivity Change in Australian Financial Services. Journal of International Financial Markets, Institutions and Money, 9(3), 303-320.

Yildirim, H. S., Philippatos, G. C. (2007). Efficiency of banks: Recent evidence from the transition economies of Europe, 1993-2003. The European Journal of Finance, 13(2), 123-143.

Yue, P. (1992). Data Envelopment Analysis and Commercial Bank Performance: A Primer with Applications to Missouri Banks. Federal Reserve Bank of St. Louis Review, 74(1), 31-45. 